\title{
Redox potential of shallow groundwater by 1-month continuous in situ potentiometric measurements
}

\author{
Seiichiro Ioka ${ }^{1} \cdot$ Hirofumi Muraoka $^{1} \cdot$ Yota Suzuki $^{2}$
}

Received: 13 March 2016/ Accepted: 23 May 2016/Published online: 4 June 2016

(c) The Author(s) 2016. This article is published with open access at Springerlink.com

\begin{abstract}
One-month continuous in situ potentiometric measurements of redox potential (Eh) were used to investigate the dominant redox processes in the shallow groundwater (i.e., $<10 \mathrm{~m}$ ) of a Holocene aquifer, Aomori City, northern Japan. The Eh values, which were determined using a platinum electrode, were $-163,-169$ and $-173 \mathrm{mV}$, respectively, for three monitoring campaigns. The temperatures and $\mathrm{pH}$ values of shallow groundwater during all three periods were approximately $12{ }^{\circ} \mathrm{C}$ and 6.6 , respectively. Dissolved oxygen and sulfide ion concentrations were not detected. Chemical analyses showed that the shallow groundwater is $\mathrm{Na}-\mathrm{Fe}-\mathrm{HCO}_{3}$ type, and contains over $40 \mathrm{mg} / \mathrm{L}$ of $\mathrm{Fe}$ (the dominant cation) and over $200 \mathrm{mg} / \mathrm{L}$ of $\mathrm{HCO}_{3}{ }^{-}$(the dominant anion). A good fit was found between measured Eh values and Eh values calculated using thermodynamic data of fine-grained goethite. This suggests that Fe redox system is related to the Eh values of shallow groundwater in the Aomori City aquifer.
\end{abstract}

Keywords In situ potentiometric measurement · Redox potential $\cdot$ Shallow groundwater $\cdot$ Aomori City $\cdot$ Northern Japan

Seiichiro Ioka

ioka@hirosaki-u.ac.jp

1 North Japan Research Institute for Sustainable Energy, Hirosaki University, 2-1-3, Matsubara, Aomori 030-0813, Japan

2 Graduate School of Science and Technology, Hirosaki University, 3 Bunkyo-cho, Hirosaki 036-8531, Japan

\section{Introduction}

Redox processes play an important role in the quality of groundwater and affect the mobility and availability of many contaminant species (Borch et al. 2010; Duro et al. 2014; Jung et al. 2015); thus, the evaluation of redox conditions in groundwater is very important. The simplest and most useful method for field-based monitoring is electrochemical measurement (oxidation-reduction potential); however, platinum electrode methods present a number of problems: (1) poisoning of the electrode for Eh measurements (Whitfield 1974; Peiffer et al. 1992); (2) disequilibrium in redox reactions (Lindberg and Runnells 1984; Stefánsson et al. 2005); and (3) mixed potentials resulting from the presence of numerous redox couples in the solution (Morris and Stumm 1967; Power and Ritche 1983; Kumar and Riyazuddin 2012; Meyer et al. 2014).

In situ (down-hole) long-term monitoring results of oxidation-reduction potential in groundwater systems with a depth of several hundred to several tens of meters suggest that $\mathrm{Fe}$ and sulfur redox systems play an important role (Grenthe et al. 1992; Gómez et al. 2006; Auqué et al. 2008; Ioka et al. 2011). However, long-term in situ potentiometric groundwater measurements have not been conducted in shallow aquifers (i.e., $<10 \mathrm{~m}$ ), except for wetlands or submerged soils.

Since the 2011 Great Tohoku earthquake (northeast Honshu, Japan), the expansion of renewable energy utilization in Japan has become essential, because renewable energy systems do not produce radioactive waste and reduce $\mathrm{CO}_{2}$ emissions. Renewable energy sources include solar energy, wind power, low head hydropower, tidal power, biomass energy, and geothermal energy. In particular, the expansion of low-enthalpy shallow geothermal energy systems that use groundwater for heating, cooling, 
and thermal storage in urban areas is required; however, current utilization remains much lower than in other countries.

The Japanese archipelago has a unique combination of geologic, geomorphic, and climatic features (e.g., recent geology, complex geomorphology, and frequently heavy rain; Oguchi et al. 2001), and as a result, groundwater resources are mainly contained in Quaternary aquifer systems hosted by Tertiary geological units (Machida et al. 2008). Both megacities and smaller Japanese cities are located on Quaternary aquifer systems (e.g., Tokyo, Osaka, Nagoya, and Aomori); therefore, the utilization of lowenthalpy shallow geothermal energy systems must focus on Quaternary aquifer systems. In particular, in cold and snowy regions (e.g., Aomori), the implementation of aquifer thermal storage in the summer season has been a requirement to meet the demand of underground heat extraction for heating rooms and melting snow in the winter season. However, aquifer thermal storage may promote microbial activity and organic matter decomposition in groundwater (Bonte et al. 2013; Jesußek et al. 2013); therefore, redox-related chemical reactions in groundwater may change or increase. Changes in electron donor (e.g., organic carbon, $\mathrm{Fe}^{2+}, \mathrm{H}_{2} \mathrm{~S}, \mathrm{H}_{2}$ ) concentrations may change oxidation-reduction potential in groundwater (e.g., Pedersen 2012). To this end, the monitoring and understanding of oxidation-reduction potential in these aquifer systems are crucial before the implementation of aquifer thermal storage.

Quaternary aquifer systems in Japan are either Holocene or Pleistocene; however, the shallow aquifers $(<10 \mathrm{~m})$ serving Japanese megacities and smaller cities are predominantly Holocene. Holocene aquifers are typically several tens of meters in thickness (Umitsu 1994), and are typically anoxic systems dominated by organic carbon degradation coupled to Fe-oxides and methanogeneous (Postma et al. 2007).

No previous studies have focused on long-term in situ potentiometric measurements of shallow groundwater in aquifers $(<10 \mathrm{~m})$. Moreover, none have examined whether the long-term continuous in situ measured Eh values correspond to the values calculated using thermodynamics data of Fe redox systems (i.e., by ferric oxyhydroxides, such as ferrihydrite, fine-grained goethite, or well-crystallized goethite) in shallow aquifers $(<10 \mathrm{~m})$. Thus, the purpose of this study was to monitor in situ measured Eh values in August, September, and October as the most likely planned period of aquifer thermal storage and to investigate whether the Eh values calculated using the thermodynamics data of ferric oxyhydroxides coincide with the measured redox potential of groundwater in shallow aquifers using long-term in situ potentiometric measurements.

\section{Site description}

This study focused on a Holocene aquifer serving Aomori City, northern Honshu, Japan (Fig. 1). This aquifer was selected because the utilization of low-enthalpy shallow geothermal energy systems is needed for snow melting and heating during the winter; thus, understanding and monitoring of groundwater quality are essential. Aomori City has a mean annual precipitation of $1300 \mathrm{~mm}$, an annual mean temperature of $10.4{ }^{\circ} \mathrm{C}$, and a maximum snow depth of $1110 \mathrm{~mm}$ in the winter season (Japan Meteorological Agency 2016).

The study area is situated on a low-lying coastal plain (the Aomori plain), which is composed of Quaternary alluvial and welded tuff deposits overlying Neogene rocks (Ito 1976; Tomidokoro 1996). Quaternary deposits in the Aomori plain have a maximum depth of $\sim 800 \mathrm{~m}$ (Tomidokoro 1996), while surface Holocene deposits have a maximum depth of 10-20 m (Kubo et al. 2006). The 10-m geological profile of the study plot contains artificial soil, silt with sand, coarse sand with quartz, fine sand, silt with sand, and fine sand with gravel (Fig. 2).

The piezometer installed at the study plot is made of polyvinylchloride (PVC) pipe with an inner diameter of $5.08 \mathrm{~cm}$ ( 2 inches). The piezometer screen, through which groundwater passes, is $6.15-8.15 \mathrm{~m}$ below ground level $(\mathrm{mbgl})$ and has a $15 \%$ open ratio. The groundwater level in the piezometer varies seasonally from 0.9 to $1.45 \mathrm{mbgl}$. The piezometer was installed in a plot at an elevation of $1.75 \mathrm{~m}$. The plot lies $1.1 \mathrm{~km}$ south of the Mutsu Bay, which is approximately $0 \mathrm{~m}$ in elevation, and $4.2 \mathrm{~km}$ north of a hill, which is $10 \mathrm{~m}$ in elevation. Thus, the study area has a very gentle terrain gradient (0.0019), and shallow groundwater in this area flows very slowly.

\section{Methodology}

The monitoring campaign included three discrete time periods in 2012: (1) 30 July to 25 August; (2) 28 August to 27 September; and (3) 30 September to 30 October.

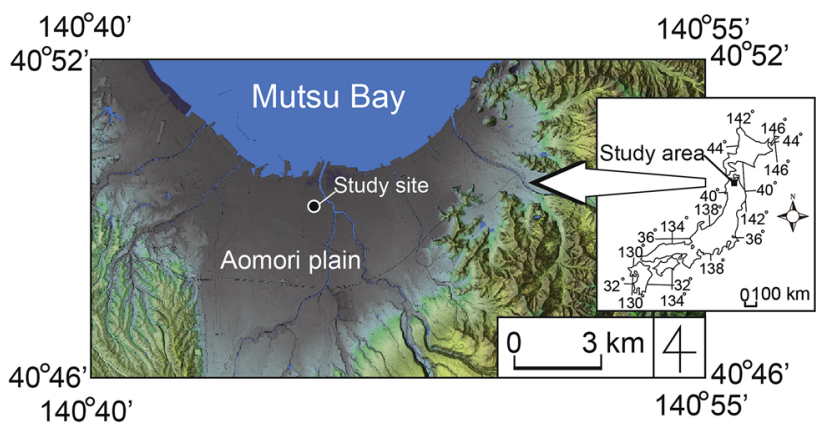

Fig. 1 Study area and location of the monitoring site 


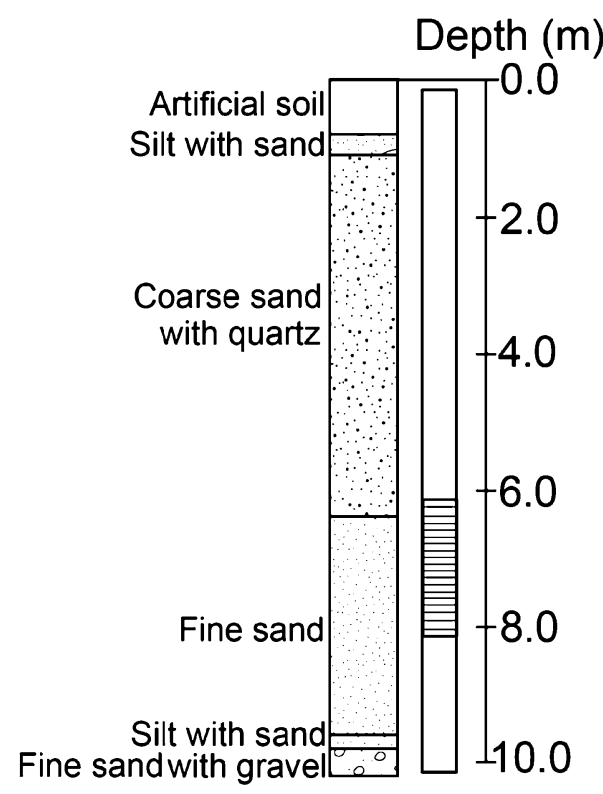

Fig. 2 Shallow (10-m) geological profile of the monitoring site

Physicochemical groundwater parameters (temperature, $\mathrm{pH}$, dissolved oxygen; DO, and oxidation-reduction potential; ORP) were measured in situ using a multi-probe (model W-22XD, Horiba Ltd. Kyoto, Japan) in the screened intake zone $(6.15-8.15 \mathrm{mbgl})$ of the piezometer.

The accuracy of the multi-probe was $\pm 1.0^{\circ} \mathrm{C}$ for temperature, \pm 0.1 for $\mathrm{pH}$, and $\pm 0.2 \mathrm{mg} / \mathrm{L}$ for DO. The $\mathrm{pH}$ electrode was calibrated with buffer solutions prepared from powder reagents of $\mathrm{pH}$ standard solutions (Code No. 150-4 and 150-7, Horiba Ltd. Kyoto, Japan). The DO electrode was calibrated using a standard solution of sodium sulfite (Code No. 192-03415, Wako Pure Chemical Industries, Ltd., Osaka, Japan). The ORP electrode was verified against an ORP standard solution made from the powder of an ORP electrode solution (Code No. 160-51, Horiba Ltd. Kyoto, Japan). The pH, DO, and ORP electrodes were again verified at the end of the monitoring campaign using the same standard solutions. The $\mathrm{pH}$ and DO electrodes showed no change over the duration of the study period; however, the ORP electrode readings at the start showed lower values (i.e., $-4,-14,-18 \mathrm{mV}$ ) than those at the end of the monitoring campaigns (i.e., -14 , $-18,-22 \mathrm{mV})$. Therefore, given the known oxidationreduction potential value of the ORP standard solution, the accuracy of the multi-probe for ORP was $\pm 22 \mathrm{mV}$.

Measured ORP values were converted into measured Eh values using the equation:

$$
\begin{aligned}
\text { Measured Eh }= & \text { measured ORP } \\
& +206-0.7(t-25) \mathrm{mV}
\end{aligned}
$$

where Eh denotes the ORP value measured using a hydrogen electrode normalized to the reference electrode, measured ORP using $\mathrm{Ag} / \mathrm{AgCl}$ (in $3.33 \mathrm{~mol} / \mathrm{L} \mathrm{KCl}$ ) as the reference electrode (model W-22XD, Horiba Ltd. Kyoto, Japan), and $t$ from the measured water temperature.

Groundwater was sampled from the piezometer on 25 August 2012, 30 September 2012, and 31 October 2012. Prior to groundwater sampling, standing water within the piezometer was removed. Groundwater samples were then collected by slowly lowering a dedicated and pre-cleaned PVC bailer (model DIK-687A, Daiki Rika Kogyo Co. Ltd., Saitama, Japan). Water samples were collected over a period of $1 \mathrm{~h}$ : First, water samples for alkalinity measurements were collected in $100 \mathrm{~mL}$ polyethylene bottles and unfiltered splits were sent to the laboratory for testing. Next, filtered (model DISMIC-25 $5_{\mathrm{HP}}, 0.2 \mu \mathrm{m}$ pore size polytetrafluoroethylene (PTFE) filter; Advantech Toyo Kaisha, Ltd., Tokyo, Japan) splits were taken for field measurements of sulfide ion $\left(\mathrm{S}^{2-}\right)$ and for laboratory measurements of cations and anions. Subsamples of the filtered waters were acidified to $\mathrm{pH}<2$ using ultrapure nitric acid, and were then used for the analysis of $\mathrm{P}, \mathrm{Fe}$, $\mathrm{Mn}, \mathrm{Si}$, and $\mathrm{Sr}$ in $100 \mathrm{~mL}$ polyethylene bottles. Nonacidified splits were retained in $100 \mathrm{~mL}$ polyethylene bottles for cation $\left(\mathrm{Na}^{+}, \mathrm{NH}_{4}^{+}, \mathrm{K}^{+}, \mathrm{Mg}^{2+}\right.$, and $\left.\mathrm{Ca}^{2+}\right)$ and anion $\left(\mathrm{F}^{-}, \mathrm{Cl}^{-}, \mathrm{Br}^{-}, \mathrm{NO}_{3}^{-}\right.$, and $\left.\mathrm{SO}_{4}{ }^{--}\right)$analysis.

Field measurements of $\mathrm{S}^{2-}$ were made using a portable colorimeter (model DR890, Hach Company, Loveland, Co, USA) and the methylene blue method (Method 8131, Hach Company), which indicates the total sulfide concentration (sum of $\mathrm{H}_{2} \mathrm{~S}, \mathrm{HS}^{-}$, and $\mathrm{S}^{2-}$ species). Concentrations of $\mathrm{Na}^{+}, \mathrm{NH}_{4}^{+}, \mathrm{K}^{+}, \mathrm{Mg}^{2+}, \mathrm{Ca}^{2+}, \mathrm{F}^{-}, \mathrm{Cl}^{-}$, $\mathrm{Br}^{-}, \mathrm{NO}_{3}{ }^{-}$, and $\mathrm{SO}_{4}{ }^{2-}$ were analyzed by ion chromatography with conductivity detection on a DX-320 (DIONEX Co., now Thermo Fisher Scientific Inc., MA, USA) at the Geothermal Engineering Laboratory, Hirosaki University. Concentrations of $\mathrm{P}, \mathrm{Fe}, \mathrm{Mn}, \mathrm{Si}$, and $\mathrm{Sr}$ were measured by inductively coupled plasma atomic emission spectrometer (Optima 7000DV, PerkinElmer Inc., MA, USA). Alkalinity was determined in the laboratory using a 876 Dosimat Plus (Metrohm AG, Herisau, Switzerland) with $\mathrm{N} / 50 \mathrm{H}_{2} \mathrm{SO}_{4}$ and is presented in terms of $\mathrm{HCO}_{3}{ }^{-}$concentration (in $\mathrm{mg} / \mathrm{L}$ of water). Analytical precision (i.e., coefficients of variation for triplicate measurements) was within $3 \%$ for $\mathrm{Na}^{+}$, $\mathrm{NH}_{4}{ }^{+}, \mathrm{K}^{+}, \mathrm{Mg}^{2+}, \mathrm{Ca}^{2+}, \mathrm{F}^{-}, \mathrm{Cl}^{-}, \mathrm{Br}^{-}, \mathrm{SO}_{4}{ }^{2-}, \mathrm{Fe}, \mathrm{Mn}, \mathrm{Si}$, and $\mathrm{Sr} ; 4 \%$ for $\mathrm{P}$; and within $11 \%$ for $\mathrm{NO}_{3}{ }^{-}$. The error in charge balance between cations and anions was less than $\pm 3 \%$ for all samples. Charge balance for groundwater samples was calculated using the aqueous speciation code from PHREEQC (Parkhurst and Appelo 2013) and its default thermodynamics database (phreeqc.dat). Saturation indices $(\mathrm{SI}=\log$ [ion activity product/solubility product]) and the activities of groundwater samples were also calculated using PHREEQC (Parkhurst and Appelo 2013) and the thermodynamics database (phreeqc.dat). 
Table 1 In situ physicochemical parameters of the groundwater

\begin{tabular}{lllll}
\hline Monitoring campaign & In situ temperature $\left({ }^{\circ} \mathrm{C}\right)$ & In situ $\mathrm{pH}$ & In situ DO $(\mathrm{mg} / \mathrm{L})$ & In situ measured Eh $(\mathrm{mV})$ \\
\hline 30 July-25 August 2012 & 12.1 & 6.64 & 0.0 & -163 \\
28 August-27 September 2012 & 12.0 & 6.63 & 0.0 & -169 \\
30 September-30 October 2012 & 12.1 & 6.68 & 0.0 & -173 \\
\hline
\end{tabular}

\section{Results}

\section{In situ temperature, pH, DO, and measured Eh}

Over the three monitoring campaigns, in situ groundwater measurements for temperature $\left(12.1,12.0\right.$, and $12.1{ }^{\circ} \mathrm{C}$, respectively), $\mathrm{pH}(6.64,6.63$, and 6.68 , respectively), and DO (always $0.0 \mathrm{mg} / \mathrm{L}$ ) remained stable (Table 1) and indicated strict anoxic conditions (Bradley et al. 2008). The in situ measured Eh values also remained very stable $(-163$, -169 and $-173 \mathrm{mV}$, respectively), and reflected the reducing conditions during each of the three monitoring periods. For each measurement period, the 1-month continuously measured Eh values decreased from approximately +50 to $-150 \mathrm{mV}$ between days 0 and 10 (Fig. 3) as a result of the slow response of the electrode (Degueldre et al. 1999), which is consistent with the observations of other studies (Grenthe et al. 1992; Auqué et al. 2008).

\section{Groundwater quality}

The sampled groundwater from the piezometer was classified as $\mathrm{Na}-\mathrm{Fe}-\mathrm{HCO}_{3}$ type (i.e., sodium-iron-bicarbonate type) water (Table 2). The dominant cation was $\mathrm{Fe}$, which always exceeded $40 \mathrm{mg} / \mathrm{L}$. Sulfide concentrations were not detected. The groundwater quality was almost stable during the three periods of monitoring.

The SI values for $\mathrm{Fe}$ minerals at given in situ conditions (i.e., measured temperature, $\mathrm{pH}$, and Eh values; Table 3) can be used to describe the effects of solubility state on solute concentrations. The SI values calculated for $\mathrm{Fe}(\mathrm{OH})_{3}$, goethite, and hematite were approximately -4.6 , 0.8 , and 3.5, respectively. Therefore, $\mathrm{Fe}(\mathrm{OH})_{3}$ was undersaturated, while goethite and hematite were oversaturated.

\section{Discussion}

To interpret the results, the measured Eh values were plotted against those calculated using heterogeneous reactions of $\mathrm{Fe}(\mathrm{III})$-oxyhydroxide (Fig. 4). The $\mathrm{HS}^{-} / \mathrm{SO}_{4}{ }^{2-}$ couple was not calculated for this comparison because sulfides were not detected. To calculate Eh using heterogeneous reactions, the following reactions were considered at $12{ }^{\circ} \mathrm{C}$ :

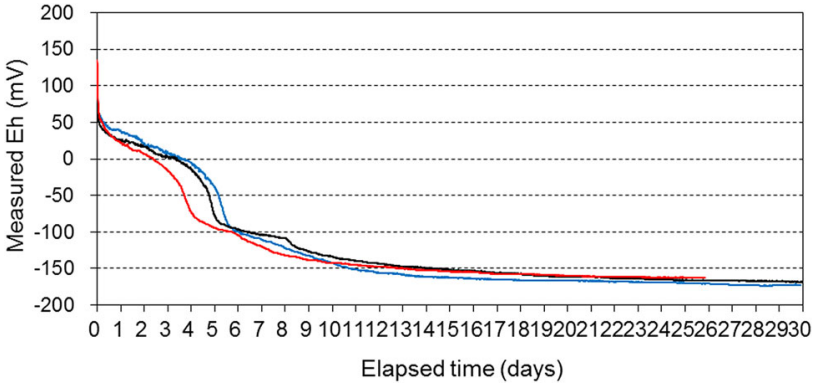

Fig. 3 Continuously measured $\mathrm{Eh}$ in shallow $(<10 \mathrm{~m})$ groundwater over approximately 1-month. Red denotes 30 July-25 August 2012. Black denotes 28 August-27 September 2012. Blue denotes 30 September-30 October 2012

$\mathrm{Fe}(\mathrm{OH})_{3(\mathrm{~s})}+3 \mathrm{H}^{+}+\mathrm{e}^{-}=\mathrm{Fe}^{2+}+x \mathrm{H}_{2} \mathrm{O}$,

where $\mathrm{Fe}(\mathrm{OH})_{3}$ denotes $\mathrm{Fe}(\mathrm{III})$-oxyhydroxide and $\mathrm{x}$ depends on mineral stoichiometry $(x=3$ for ferrihydrite, and $x=2$ for goethite). The calculated Eh for each reaction ignores activity coefficients, using

$\mathrm{Eh}=E^{0 *}-2.303(R T / F)\left(3 \mathrm{pH}+\log \left[\mathrm{Fe}^{2+}\right]\right)$,

where

$\mathrm{E}^{0 *}=\mathrm{E}^{0}+2.303(R T / F) \log \mathrm{K}^{*}$,

where $R, T$, and $F$ are the gas constant $(=8.3143 \mathrm{~J} / \mathrm{mol} / \mathrm{K})$, temperature, and Faraday constant $(=96,485$ coulombs/ mol), respectively; $E^{0}$ is the standard half-cell potential for the reaction $\mathrm{Fe}^{2+}=\mathrm{Fe}^{3+}+\mathrm{e}^{-}\left(=0.755 \mathrm{~V}\right.$ at $\left.12{ }^{\circ} \mathrm{C}\right)$; $\left[\mathrm{Fe}^{2+}\right]$ is the molarity of $\mathrm{Fe}^{2+}$; and $K^{*}$ is the equilibrium constant of the reaction (Grenthe et al. 1992; Arthur et al. 2006):

$\mathrm{Fe}(\mathrm{OH})_{3(\mathrm{~s})}+3 \mathrm{H}^{+}=\mathrm{Fe}^{3+}+x \mathrm{H}_{2} \mathrm{O}$.

The minerals considered were ferrihydrite, which precipitate from rapid hydrolysis of $\mathrm{Fe}$ (III) or the oxidation of $\mathrm{Fe}(\mathrm{II})$, and goethite, which is the most abundant $\mathrm{Fe}$ (III)-oxyhydroxide in cool climates (Langmuir 1997). The $\log K^{*}$ of ferrihydrite $\left(\log K^{*}=4.00\right)$ was evaluated for an in situ temperature of $12.0{ }^{\circ} \mathrm{C}$ using the Rxn program Geochemist's Workbench version 9.09 (Bethke and Yeakel 2011) with the thermo_minteq thermodynamic database. The $\log K^{*}$ of goethite and hematite used for calculation of SI values $\left(\log K^{*}=-0.516\right.$ and -2.977$)$ 
Table 2 Chemical composition (mg/L) of groundwater samples

\begin{tabular}{llll}
\hline $\begin{array}{l}\text { Sampling } \\
\text { date }\end{array}$ & $\begin{array}{l}25 \text { August } \\
2012\end{array}$ & $\begin{array}{l}30 \text { September } \\
2012\end{array}$ & $\begin{array}{l}31 \text { October } \\
2012\end{array}$ \\
\hline $\mathrm{F}^{-}$ & 0.063 & 0.063 & 0.061 \\
$\mathrm{Cl}^{-}$ & 20.0 & 20.2 & 19.8 \\
$\mathrm{Br}^{-}$ & 0.120 & 0.121 & 0.116 \\
$\mathrm{NO}_{3}{ }^{-}$ & $<0.01$ & 0.02 & 0.01 \\
$\mathrm{SO}_{4}{ }^{2-}$ & 0.04 & 0.05 & 0.04 \\
$\mathrm{~S}^{2-}$ & $n / m$ & $n / m$ & $n / d$ \\
$\mathrm{HCO}_{3}{ }^{-}$ & 216 & 208 & 208 \\
$\mathrm{Na}^{+}$ & 24.2 & 24.1 & 23.4 \\
$\mathrm{NH}_{4}{ }^{+}$ & 0.355 & 0.342 & 0.328 \\
$\mathrm{~K}^{+}$ & 5.2 & 5.1 & 5.0 \\
$\mathrm{Mg}^{2+}$ & 9.82 & 9.76 & 9.30 \\
$\mathrm{Ca}^{2+}$ & 11.8 & 11.9 & 11.5 \\
$\mathrm{P}$ & 0.36 & 0.36 & 0.30 \\
$\mathrm{Total}^{2+} \mathrm{Fe}$ & 40.0 & 41.2 & 40.3 \\
$\mathrm{Mn}$ & 0.962 & 1.02 & 0.942 \\
$\mathrm{Sr}$ & 0.068 & 0.069 & 0.070 \\
$\mathrm{Si}$ & 22.9 & 21.8 & 22.3 \\
\hline
\end{tabular}

$n / m$ no measurement, $n / d$ not detected

Table 3 Saturation indices of $\mathrm{Fe}(\mathrm{OH})_{3}$, goethite, and hematite

\begin{tabular}{llll}
\hline Date & $\mathrm{Fe}(\mathrm{OH})_{3}$ & Goethite & Hematite \\
\hline 25 August 2012 & -4.57 & 0.84 & 3.62 \\
30 September 2012 & -4.69 & 0.72 & 3.38 \\
31 October 2012 & -4.62 & 0.79 & 3.52 \\
\hline
\end{tabular}

Values calculated from groundwater compositions (Table 2) using PHREEQC (Parkhurst and Appelo 2013) and the phreeqc.dat thermodynamic database

was evaluated for an in situ temperature of $12.0{ }^{\circ} \mathrm{C}$ using the Rxn program Geochemist's Workbench version 9.09 (Bethke and Yeakel 2011) with the thermo_phreeqc thermodynamic database. Particle size affects the goethite solubility (Langmuir 1997); therefore, the $\log K^{*}$ of coarsegrained goethite was corrected using the data (Table 4) and the Van't Hoff equation (Zhu and Anderson 2002). The in situ temperature $\log K^{*}$ of fine-grained goethite was calculated using (Stumm and Morgan 1996):

$\log K^{*}=\log K_{(S=0)}^{*}+\left((2 / 3) \gamma_{s}\right) /(2.3 R T) S$

where $\gamma_{\mathrm{s}}$ and $S$ are the interfacial energy $\left(=1.2552 \mathrm{~J} / \mathrm{m}^{2}\right)$ (Langmuir 1997) and surface area of a mol of the solid (=13500 $\mathrm{m}^{2} / \mathrm{mol}$ ), respectively (Langmuir 1997). The log $K^{*}{ }_{(S=0)}$ represents the in situ temperature $\log K^{*}$ of coarsegrained goethite. These results for $\log K^{*}$ were -1.65 for coarse-grained goethite and 0.42 for fine-grained goethite.

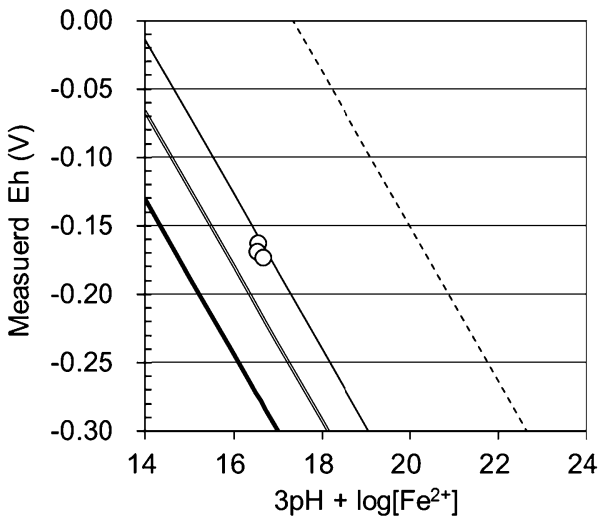

Fig. 4 Calculated Eh [assuming dissolution/precipitation reactions involving an $\mathrm{Fe}(\mathrm{III})$-oxyhydroxide (lines) redox] versus in situ measured Eh (circles) in groundwater samples. The dashed line denotes ferrihydrite. The double lines denote goethite. The normal and bold lines denote fine-grained and coarse-grained goethite, respectively

Table 4 Reaction equations and thermodynamic data $(\mathrm{kJ} / \mathrm{mol})$ at $25{ }^{\circ} \mathrm{C}$ and $1 \mathrm{~atm}$ pressure

\begin{tabular}{lll}
\hline Reaction & $\Delta G_{\mathrm{r}}^{\mathrm{o}}$ & $\Delta H_{\mathrm{r}}^{\mathrm{o}}$ \\
\hline Goethite $+3 \mathrm{H}^{+}=\mathrm{Fe}^{3+}+2 \mathrm{H}_{2} \mathrm{O}$ & 12.07 & -58.41
\end{tabular}

Data used to calculate in situ $\log K^{*}$ for coarse-grained goethite (Stumm and Morgan 1996; Langmuir 1997)

The $\log K^{*}(=-0.516)$ for goethite used for calculation of SI value is between that for coarse-grained goethite and for fine-grained goethite.

The lines created from Eq. 3 all had the same Nernstian slopes and were offset by an amount determined by the log $K^{*}$ values selected for ferrihydrite, fine-grained goethite, goethite or coarse-grained goethite (Fig. 4). The measured Eh values from each of the three monitoring periods plotted near the fine-grained goethite line. These results suggest that the Eh of shallow groundwater $(<10 \mathrm{~m})$ in Aomori City, northern Japan, is related to heterogeneous reactions involving fine-grained goethite.

\section{Conclusion}

In this study, we monitored the Eh values of groundwater in a shallow Holocene aquifer $(<10 \mathrm{~m})$ using 1-month continuous in situ potentiometric measurements. The results of this study showed that the in situ measured Eh values were $-163,-169$, and $-173 \mathrm{mV}$, respectively, for three monitoring campaigns. The good fit between the measured Eh values and the calculated Eh values suggests that the Fe redox system is related to the Eh values in the shallow groundwater $(<10 \mathrm{~m})$ of Aomori City. In future, 
continuous in situ Eh monitoring, as an indicator of groundwater quality, would be applicable to other cold and snowy regions (e.g., Akita City and Yamagata City) where aquifer thermal storage is planned.

Acknowledgments This study was partially funded by the Kurita Water and Environment Foundation (No. 23020). Figure 1 was drawn using Kashmir 3D.

Open Access This article is distributed under the terms of the Creative Commons Attribution 4.0 International License (http:// creativecommons.org/licenses/by/4.0/), which permits unrestricted use, distribution, and reproduction in any medium, provided you give appropriate credit to the original author(s) and the source, provide a link to the Creative Commons license, and indicate if changes were made.

\section{References}

Arthur RC, Iwatsuki T, Sasao E, Metcalfe R, Amano K, Ota K (2006) Geochemical constraints on the origin and stability of the tono uranium deposit, Japan. Geochem: Explor Environ, Anal 6:33-48. doi:10.1144/1467-7873/05-081

Auqué L, Gimeno MJ, Gómez J, Nilsson A-C (2008) Potentiometrically measured $\mathrm{Eh}$ in groundwaters from the Scandinavian Shield. Appl Geochem 23:1820-1833. doi:10.1016/j.apgeochem. 2008.02.016

Bethke CM, Yeakel S (2011) GWB Essential Guide. Aqueous Solutions LLC, Champaign

Bonte M, Röling WFM, Zaura E, Van der Wielen PWJJ, Stuyfzand PJ, Van Breukelen BM (2013) Impacts of shallow geothermal energy production on redox processes and microbial communities. Environ Sci Technol 47:14476-14484. doi:10.1021/ es4030244

Borch T, Kretzschmar R, Kappler A, van Chappellen P, Ginder-vogel M, Voegelin A, Campbell K (2010) Biogeochemical redox processes and their impact on contaminant dynamics. Environ Sci Technol 44:15-23. doi:10.1021/es9026248

Bradley PM, Chapelle FH, Löffler FE (2008) Anoxic mineralization: environmental reality or experimental artifact? Ground Water 28:47-49. doi:10.1111/j.1745-6592.2007.00186.x

Degueldre C, Rocchiccioli F, Laube A (1999) Accelerated measurement of groundwater redox potentials: method and application. Analy Chim Acta 396:23-31. doi:10.1016/S0003-2670(99)00352-9

Duro L, Domènech C, Grivé M, Roman-Ross G, Bruno J, Källström K (2014) Assessment of the evolution of the redox conditions in a low and intermediate level nuclear waste repository (SFR1, Sweden). Appl Geochem 49:192-205. doi:10.1016/j.apgeochem. 2014.04.015

Gómez P, Turrero ML, Garrralón A, Peña J, Buil B, de la Cruz B, Sánchez M, Sánchez DM, Quejido A, Bajos C, Sánchez L (2006) Hydrogeochemical characteristics of deep groundwaters of the Hesperian Massif (Spain). J Iber Geol 32:113-131

Grenthe I, Stumm W, Laaksuharju M, Nilsson A-C, Wikberg P (1992) Redox potentials and redox reactions in deep groundwater systems. Chem Geol 98:131-150. doi:10.1016/0009-2541(92)90095-M

Ioka S, Sakai T, Igarashi T, Ishijima Y (2011) Determination of redox potential of sulfidic groundwater in unconsolidated sediments by long-term continuous in situ potentiometric measurements. Environ Monit Assess 178:171-178. doi:10.1007/s10661-010-1680-4

Ito Y (1976) Chuseki-so and land subsidence in Aomori plain. Hirodai-chiri 12:10-14
Japan Meteorological Agency (2016) Average values in Aomori City. Available online: http://www.data.jma.go.jp/obd/stats/etrn/view/ nml_sfc_ym.php?prec_no $=31 \& b l o c k \_n o=47575 \& y e a r=\& m o n t h=$ $\&$ day $=\&$ view $=$ Accessed 11 February 2016

Jesußek A, Köber R, Grandel S, Dahmke A (2013) Aquifer heat storage: sulphate reduction with acetate at increased temperatures. Environ Earth Sci 69:1763-1771. doi:10.1007/s12665012-2009-0

Jung HB, Zheng Y, Rahman MW, Rahman MM, Ahmed KM (2015) Redox zonation and oscillation in the hyporheic zone of the Ganges-Brahmaputra-Meghna Delta: implications for the fate of groundwater arsenic during discharge. Appl Geochem 63:647-660. doi:10.1016/j.apgeochem.2015.09.001

Kubo J, Tsuji S, Murata T, Tsuji K, Goto K (2006) Paleoenvironments and geomorphological evolution of Aomori plain since the Last Glacial period. Jpn J Histor Bor Special issue $2: 7-17$

Kumar AR, Riyazuddin P (2012) Seasonal variation of redox species and redox potentials in shallow groundwater: a comparison of measured and calculated redox potentials. J Hydrol 444-445:187-198. doi:10.1016/j.jhydrol.2012.04.018

Langmuir D (1997) Aqueous environmental geochemistry. PrenticeHall Inc, Upper Sadlle River

Lindberg RD, Runnells DD (1984) Ground water redox reactions: an analysis of equilibrium state applied to Eh measurements and geochemical modeling. Science 225:925-927. doi:10.1126/ science.225.4665.925

Machida I, Suzuki Y, Takeuchi M (2008) The ${ }^{14} \mathrm{C}$ age of confined groundwater in a sandy-muddy Pleistocene aquifer. In: Taniguchi M, Holman IP (eds) Groundwater Response to Changing Climate. CRC Press, Balkema, pp 67-78

Meyer D, Prien RD, Dellwig O, Waniek JJ, Schulz-bull DE (2014) Electrode measurements of the oxidation reduction potential in the Gotland Deep using a moored profiling instrumentation. Estuar Coast Shelf Sci 141:26-36. doi:10.1016/j.ecss.2014.02. 001

Morris JC, Stumm W (1967) Redox equilibria and measurements of potentials in the aquatic environment. Adv Chem Ser 67:270-285. doi:10.1021/ba-1967-0067.ch013

Oguchi T, Saito K, Kadomura H, Grossman M (2001) Fluvial geomorphology and paleohydrology in Japan. Geomorphology 39:3-19. doi:10.1016/S0169-555X(01)00048-4

Parkhurst J, Appelo CAJ (2013) Description of input and examples for PHREEQC version 3-A computer program for speciation, batch-reaction, one-dimensional transport, and inverse geochemical calculations. In US Geological Survey Techniques and Methods, Book 6; US Department of the Interior, US Geological Survey

Pedersen $\mathrm{K}$ (2012) Influence of $\mathrm{H}_{2}$ and $\mathrm{O}_{2}$ on sulfate-reducing activity of a subterranean community and the coupled response in redox potential. FEMS Microbial Ecol 82:653-655. doi:10.1111/j. 1574-6941.2012.01434.x

Peiffer S, Klemm O, Pecher K, Hollerung R (1992) Redox measurements in aqueous solutions-a theoretical approach to data interpretation, based on electrode kinetics. J Contam Hydrol 10:1-18. doi:10.1016/0169-7722(92)90041-C

Postma D, Larsen F, Hue NTM, Duc MT, Viet PM, Nhan PQ, Jessen S (2007) Arsenic in groundwater of the Red River floodplain, Vietnam: controlling geochemical processes and reactive transport modeling. Geochim Cosmochim Acta 71:5054-5071. doi:10.1016/j.gca.2007.08.020

Power GP, Ritche M (1983) Mixed potentials. J Chem Edu 60:1022-1026. doi:10.1021/ed060p1022

Stefánsson A, Arnórsson S, Sveinbjörnsdóttir ÁE (2005) Redox reactions and potentials in natural waters at disequilibrium. Chem Geol 221:289-311. doi:10.1016/j.chemgeo.2005.06.003 
Stumm W, Morgan JJ (1996) Aquatic chemistry, 3rd edn. Wiley, New York

Tomidokoro K (1996) Land subsidence in Aomori plain. Hirodaichiri 32:47-54

Umitsu M (1994) Late Quaternary Environment and Landform Evolution of Riverine Coastal Lowlands. Kokon Shoin Publishers, Tokyo
Whitfield M (1974) Thermodynamics limitations on the use of the platinum electrode in Eh measurements. Limnol Oceanogr 19:857-865. doi:10.4319/lo.1974.19.5.0857

Zhu C, Anderson G (2002) Environmental applications of geochemical modelling. Cambridge University Press, Cambridge 